\title{
Morpho-anatomical and physiological aspects of Passiflora edulis Sims (passion fruit) subjected to flooded conditions during early developmental stages
}

\author{
Kamilla Pacheco Govêa \\ Antonio Rodrigues da Cunha Neto \\ Natália Martins Resck \\ Letícia Leite Moreira \\ Valdir Veroneze Júnior \\ Frederico Luiz Pereira \\ Marcelo Polo \\ Thiago Corrêa de Souza * \\ Universidade Federal de Alfenas, Instituto de Ciências da Natureza \\ Laboratório de Biotecnologia Ambiental \& Genotoxicidade \\ Rua Gabriel Monteiro da Silva, 700, CEP 37130-000, Alfenas - MG, Brasil \\ * Autor para correspondência \\ thiagonepre@hotmail.com
}

Submetido em 09/03/2018

Aceito para publicação em 09/08/2018

\section{Resumo}

Aspectos morfoanatômicos e fisiológicos de Passiflora edulis Sims (maracujazeiro) submetido a condições alagadas em estágios iniciais de desenvolvimento. $\mathrm{O}$ alagamento no solo é um fenômeno que reduz a sobrevivência, o crescimento e o desenvolvimento de plantas, podendo ocasionar queda na produtividade quando essas são agricultáveis. O maracujazeiro (Passiflora edulis Sims) é uma frutífera comercial com propriedades medicinais cuja produção incentiva a irrigação; e não são encontrados estudos que apresentem efeitos do excesso de água no solo sobre estas plantas. O objetivo deste trabalho foi verificar alterações morfoanatômicas e fisiológicas no desenvolvimento inicial de plântulas de maracujazeiro expostas a diferentes níveis de água no solo. As plântulas foram organizadas em três tratamentos: solo com capacidade de campo, pré-submergido e alagado. Após sete dias, foram feitas análises de trocas gasosas, potencial hídrico, quantificação de prolina e cortes anatômicos de raízes. O solo alagado influencia as trocas gasosas e afeta negativamente a fotossíntese. Não houve alterações no potencial hídrico nem na quantificação de prolina entre os tratamentos. Os tratamentos pré-submergido e alagado apresentaram aerênquima e aumento no diâmetro das raízes e na espessura das barreiras apoplásticas e do córtex. O maracujazeiro apresentou alterações fisiológicas e anatômicas que permitiram sua sobrevivência em condições pré-submergidas e alagadas, o que significa que plântulas jovens dessa espécie suportam maiores quantidades de água no solo.

Palavras-chave: Anatomia radicular; Passifloraceae; Potencial hídrico; Prolina; Trocas gasosas 


\section{Abstract}

Soil flooding is a phenomenon that reduces survival, growth and development of plants, and can cause a decrease in crop productivity. Passion fruit (Passiflora edulis Sims) is commercialized, has medicinal properties, and can benefit from irrigation when cultivated. However, there are no studies showing the effects of excess water in the soil on this plant. The objective of this study was to verify morpho-anatomical and physiological changes during early developmental stages of passion fruit seedlings exposed to different water levels in the soil. Seedlings were organized into three treatments: soil at field capacity, pre-submerged soil and flooded soil. After seven days, analyses of gas exchange, water potential, proline content and anatomical root sections were performed. The flooded soil had important effects on gas exchange and photosynthesis. No changes in water potential or proline content were verified among the different treatments. The pre-submerged and flooded treatments resulted in increased root diameter and thickness of apoplastic barriers and the cortex. Passion fruit exhibited physiological and anatomical responses that allowed it to survive in pre-submerged and flooded conditions.

Key words: Gas exchange; Passifloraceae; Proline; Root anatomy; Water potential

\section{Introduction}

Plants in their natural environment or in agricultural areas may undergo periods of stress due to adverse, short- or long-term conditions. In order to withstand such conditions, many plants develop mechanisms that allow them to survive (HENRIQUE et al., 2010).

Soil flooding is an adverse condition caused naturally (e.g., by periods of heavy rainfall, bad natural soil drainage and catastrophes due to global climate change) or artificially (e.g., by dams or irrigation) (HENRIQUE et al., 2010; SILVEIRA et al., 2015). It is a phenomenon that drastically reduces survival, growth and development performance of terrestrial plants and often leads to the erosion of natural and cultivated biodiversity (VOESENEK et al., 2006; BUDKE et al., 2010). This occurs because the concentration of oxygen available to plant roots rapidly decreases under these conditions. In addition, there are physical, chemical and microbiological changes in the soil (GONÇALVES et al., 2012).

The major limitation to plant growth under flooding is the reduction of available oxygen in the soil. In drained soils, the air passes through pores and provides enough oxygen for root respiration. Under flooded conditions, the air in soil pores is replaced by water and the oxygen available to the roots decreases. This is because the lower solubility and diffusion rate of oxygen in water reduces oxygen exchange between the atmosphere and the flooded soil (CALBO et al., 1998; COLMER; PEDERSEN, 2008). Low available oxygen, or its absence, may lead to several disturbances in plants, such as changes in the respiratory rate of roots and photosynthetic efficiency, due to the reduction in photochemical energy yield (BLOM; VOESENEK, 1996). Some plants exhibit chlorosis, premature wilting, and a decrease in water potential and nutrient concentration in the leaves, besides a decrease in growth rate (COELHO et al., 2013).

Plants tolerant to flooded conditions have the capacity to develop mechanisms to support oxygen depletion and possible increases in toxic compounds associated with oxidative stress (SHINOZAKI et al., 2015). According to Gonçalves et al. (2012) these mechanisms are complex and involve a combination of physiological, anatomical and morphological changes. The most evident aspects are leaf expansion, leaf abscission induction, senescence, reduction of gas exchange, activation of anaerobic metabolism, reduction of biomass accumulation, hypertrophy of lenticels and stems, and formation of adventitious roots, aerenchyma and pneumatophores (COLMER; PEDERSEN, 2008; HENRIQUE et al., 2010; OLIVEIRA; JOLY, 2010).

Passion fruit (Passiflora edulis Sims) belongs to the family Passifloraceae, is probably native to Brazil, and has a wide geographic distribution. It can be cultivated in tropical and subtropical regions, which has led to its commercializing in several countries. Its fruits are consumed fresh and are used in the production of juices, pulps, liquors, sweets and cosmetics. In addition, they have medicinal properties, such as a natural calming 
effect, which demonstrates the economic relevance of their production (MELETTI, 2011). The soil properties indicated for cultivating passion fruit are deep, sandy or slightly clayey and well drained, since flooded conditions lead to diseases in the root system (LIMA et al., 1994).

The search for a plant genotype that is water tolerant has increased considerably, since flooding and pre-submergence occur repeatedly in several regions of the planet. In addition, there is an incentive to irrigate passion fruit crops, especially at early developmental stages (COELHO et al., 2013; ROTONDANO; MELO, 2015). The analysis of morpho-physiological parameters, carried out in this study, provides subsidies for the genetic enhancement of Passiflora edulis, since elucidating characteristics that provide stress tolerance to flooding can be used as a marker (phenotyping) to aid in the traditional genetic enhancement of plants. Therefore, the option to establish passion fruit in regions with higher amounts of water in the soil is important since natural climatic conditions and irrigation can influence the development of this plant.

The objective of this study was to verify morphoanatomical and physiological changes during early developmental stages of passion fruit seedlings exposed to different water levels in the soil.

\section{Materials and Methods}

\section{Site and treatments}

Twelve Passiflora edulis Sims seedlings, 15 days after germination, were transplanted with the clods to containers that were $13.5 \mathrm{~cm}$ in diameter at the top and $11 \mathrm{~cm}$ in diameter at the bottom. The substrate Mococa ${ }^{\circledR}$ (comprising peat, pine and charcoal powder, enriched with macro- and micronutrients) was used to complete the volume of the containers and to wrap the clods.

The plants were organized into three treatments (and remained under the treatments for seven days):

a) Soil at field capacity (control - drained),

b) Pre-submerged soil (with water at ground level, not drained) and

c) Flooded soil (plant submersed in water up to the first node, $2 \mathrm{~cm}$ above the surface).

\section{Gas exchange analyses}

After seven days of treatment, a leaf of each plant (second node from the apex) was analyzed using a portable photosynthesis system (IRGA, Model LI6400XT, Li-Cor, Lincoln, Nebraska, USA) in an artificial light chamber (LI-6400-02B RedBlue, Li-Color). All measurements were made in the morning, between 9 and $11 \mathrm{am}$, with the temperature set at $25^{\circ} \mathrm{C}$. Each analyzed leaf was fully expanded and physiologically mature. The parameters leaf photosynthetic rate $(\mathrm{Pn})$, stomatal conductance $(\mathrm{gs})$, intracellular concentration of $\mathrm{CO}_{2}(\mathrm{Ci})$ and instantaneous carboxylation efficiency (ICE - ratio between photosynthesis and intracellular concentration of $\mathrm{CO}_{2}$ ) were evaluated.

\section{Water potential analyses}

The leaf water potential (LWP) was determined in the plants with the same leaves that were subjected to the IRGA analysis, using a Scholander pump (Model 3115, Soil Moisture Equipment, Corp., Santa Barbara, California). The measurements were performed shortly after the IRGA analysis, between 9 and $11 \mathrm{am}$, and the data were expressed as bars.

\section{Proline content determination}

The method described by Torello and Rice (1986) was used with minor modifications. Acid ninhydrin was prepared by heating $2.5 \mathrm{~g}$ of ninhydrin, $60 \mathrm{~mL}$ of acetic acid and $40 \mathrm{~mL}$ of $6 \mathrm{M}$ phosphoric acid, stirred until dissolved. Samples of approximately $0.1 \mathrm{~g}$ of fresh leaf matter were homogenized in a porcelain mortar with 10 $\mathrm{mL}$ of $3 \%$ sulfosalicylic acid and filtered with filter paper. In a test tube containing $2 \mathrm{~mL}$ of the supernatant, $2 \mathrm{~mL}$ of acid ninhydrin and $2 \mathrm{~mL}$ of glacial acetic acid were added. Subsequently, the supernatants were vigorously homogenized in a shaker incubator for 60 minutes and heated in a water bath for $1 \mathrm{~h}$ at $100^{\circ} \mathrm{C}$. After cooling by immersion in an ice bath, color intensity was measured at $520 \mathrm{~nm}$ with a spectrophotometer (Biochron, Libra S22). The absorbances obtained were compared with the standard curve of proline and the results were expressed in $\mu \mathrm{mol}$ proline $\mathrm{g}^{-1}$ fresh matter. 


\section{Root anatomy evaluation}

To evaluate the effects of water stress on root anatomy, the main root of each replicate was collected after seven days of exposure to the treatments and cross sections were made, according to Souza et al. (2012), in the region $0.5 \mathrm{~cm}$ from the root apex. Microscope slides were then prepared, stained with Safrablau (safranin + astra blue) and photographed under an AXIO ZEISS SCOPE A1 optical microscope coupled to a digital camera. The parameters evaluated were root diameter (RD), epidermal thickness (EpT), thickness of the cortex (TC), thickness of the endoderm (TEn), number of xylem (NX), diameter of xylem (DX), diameter of phloem (DP) and thickness of aerenchyma (TA). Four photos were evaluated per replication.

All of these measurements were made with the image analysis program AxionVision SE64 Rel 4.8, using calibrations made with a microscopic ruler photographed at the same magnification as the photomicrographs.

\section{Statistical analyses}

The experiment was completely randomized with three treatments with four replicates. The data were collected at the end of the seventh day, submitted to an analysis of variance (ANOVA), and the means obtained were compared by the Scott-Knott test at 5\% significance using the program Sisvar version 5.6.

\section{Results}

None of the plants died during the seven days of treatment exposure, nor did they show any leaf abscission. For the leaf gas exchange analyses (Table 1), all parameters evaluated showed a statistically significant difference $(\mathrm{p}<0.05)$ among treatments. The parameters involving leaf photosynthetic rate $(\mathrm{Pn})$, stomatal conductance (gs) and intracellular concentration of $\mathrm{CO}_{2}$ (Ci) did not differ statistically in plant groups a and b. However, they differed from those submitted to the flooded condition (group c). It was found that flooding decreases Pn, gs and Ci compared to the other two treatments. For instantaneous carboxylation efficiency (ICE), the three treatments differed from each other. It was verified that plants submitted to soil conditions at field capacity have higher ICE, followed by the presubmerged treatment and then the flooded treatment.

Regarding leaf water potential (LWP) and proline content, there was no significant statistical difference $(p>0.05)$ among the three treatments (Table 2).

TABLE 2: Results for leaf water potential (LWP) and proline content of passion fruit plants exposed to different water levels in the soil.

\begin{tabular}{lcc}
\hline \multicolumn{1}{c}{ Treatments } & $\begin{array}{c}\text { Leaf water } \\
\text { potential (LWP) } \\
(\text { Bar })\end{array}$ & $\begin{array}{c}\text { Proline } \\
\left(\mu \mathrm{mol.g} \mathbf{g}^{-1}\right)\end{array}$ \\
\hline a) Field capacity & $13.62 \mathrm{a}$ & $0.04 \mathrm{a}$ \\
b) Pre-submerged & $11.52 \mathrm{a}$ & $0.02 \mathrm{a}$ \\
c) Flooded & $9.52 \mathrm{a}$ & $0.04 \mathrm{a}$ \\
\hline
\end{tabular}

Means followed by the same letter in the column do not differ statistically by the Scott-Knott test at $5 \%$ probability.

For the root anatomy data, the parameters number of xylem (NX), diameter of xylem (DX) and diameter of phloem (DP) did not have a significant statistical difference $(p>0.05)$ among treatments (Table 3$)$.

TABLE 1: Gas exchange analysis of passion fruit plants exposed to different water levels in the soil.

\begin{tabular}{lcccc}
\hline \multirow{2}{*}{ Treatments } & Pn & gs & Ci & ICE \\
\cline { 2 - 5 } & $\left(\mu \mathrm{mol} . \mathbf{m}^{-2} \cdot \mathbf{s}^{-1}\right)$ & $\left(\mathbf{s . c m}^{-1}\right)$ & $\left(\mu \mathrm{mol} . \mathrm{mol}^{-1}\right)$ & $\left(\mu \mathrm{mol} \mathrm{m}^{-2} \cdot \mathbf{s}^{-1} / \mu \mathbf{m o l ~ m o l}^{-1}\right)$ \\
\hline a) Field capacity & $8.56 \mathrm{a}$ & $0.19 \mathrm{a}$ & $275.48 \mathrm{a}$ & $0.03 \mathrm{a}$ \\
b) Pre-submerged & $7.43 \mathrm{a}$ & $0.20 \mathrm{a}$ & $288.72 \mathrm{a}$ & $0.02 \mathrm{~b}$ \\
c) Flooded & $3.76 \mathrm{~b}$ & $0.04 \mathrm{~b}$ & $202.87 \mathrm{~b}$ & $0.01 \mathrm{c}$ \\
\hline
\end{tabular}

Means followed by the same letter in the column do not differ statistically by the Scott-Knott test at $5 \%$ probability. 
The parameter measurements for root diameter (RD), epidermal thickness (EpT), thickness of the cortex (TC) and thickness of the endoderm (TEn) showed significant differences $(\mathrm{p}<0.05)$ only for treatment a (plants submitted to soil at field capacity); the other two treatments did not differ from each other. An increase was verified for RD, EpT, TC and TEn in the passion fruit roots exposed to pre-submerged and flooded soils compared to roots exposed to the soil at field capacity (Figure 1).
TABLE 3: Results for anatomical parameters of passion fruit roots exposed to different water levels in the soil.

\begin{tabular}{lccc}
\hline \multirow{2}{*}{ Treatments } & NX & DX & DP \\
\cline { 2 - 4 } & $(\boldsymbol{\mu m})$ & $(\mu \mathrm{m})$ & $(\boldsymbol{\mu m})$ \\
\hline a) Field capacity & $2.81 \mathrm{a}$ & $17.68 \mathrm{a}$ & $25.10 \mathrm{a}$ \\
b) Pre-submerged & $4.37 \mathrm{a}$ & $19.80 \mathrm{a}$ & $50.70 \mathrm{a}$ \\
c) Flooded & $3.62 \mathrm{a}$ & $28.29 \mathrm{a}$ & $77.66 \mathrm{a}$ \\
\hline
\end{tabular}

Means followed by the same letter in the column do not differ statistically by the Scott-Knott test at $5 \%$ probability.

FIGURE 1: Anatomical parameters verified in passion fruit roots exposed to different water levels in the soil. A - Root diameter (RD); B - Epidermal thickness (EpT); C - Thickness of the cortex (TC); D - Thickness of endoderm (TEn); E - Thickness of aerenchyma (TA). Columns followed by the same letter in each graph do not differ statistically by the Scott-Knott test at $5 \%$ probability.

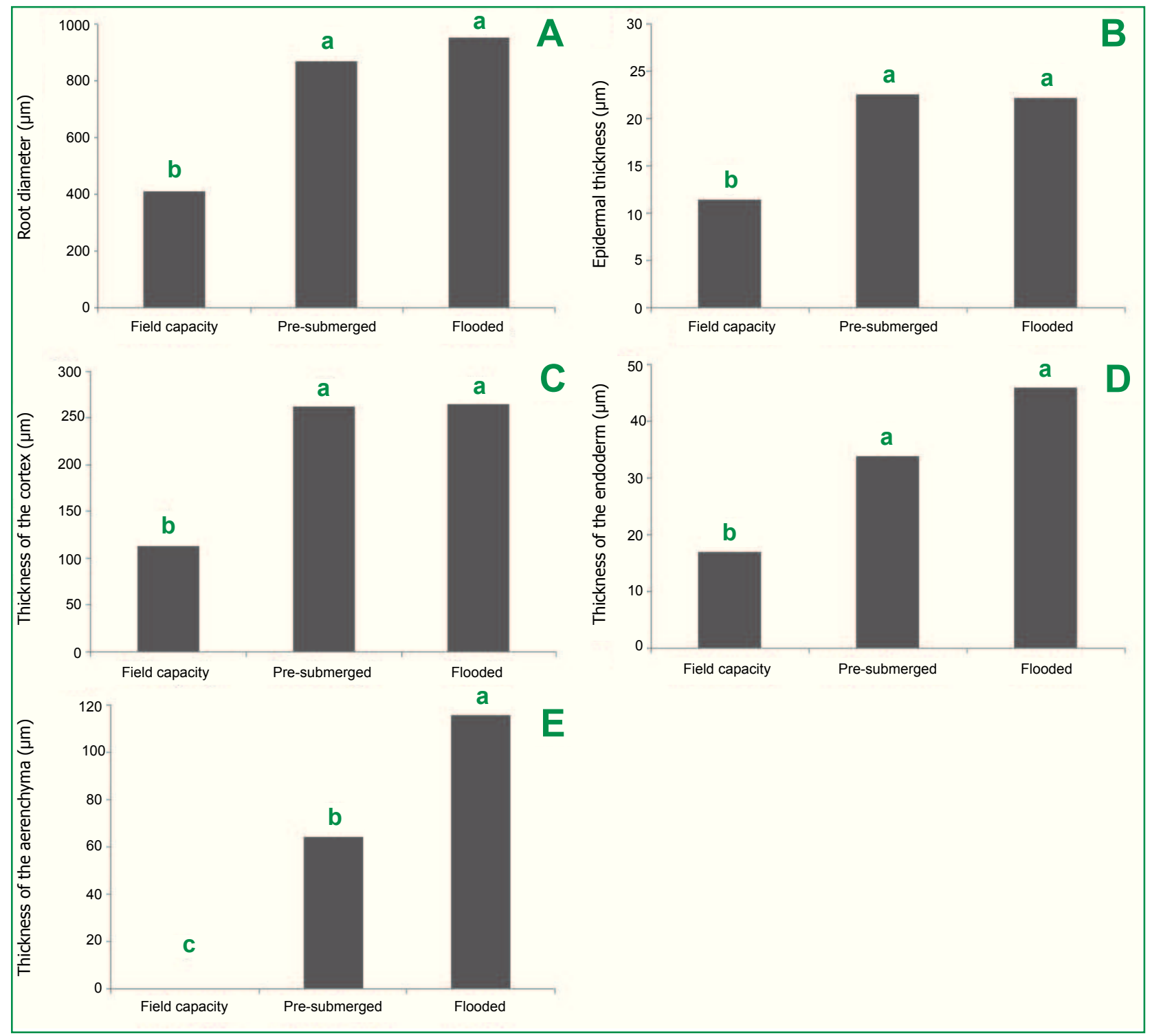


The roots of samples submitted to soil at field capacity (group a) did not have aerenchyma, while those submitted to the other two treatments had this anatomical modification. For thickness of aerenchyma (TA), there was a significant difference $(\mathrm{p}<0.05)$ among all treatments (Figure 1 and Figure 2).

FIGURE 2: Cross sections of passion fruit roots exposed to different water levels in the soil. A) Field capacity. B) Pre-submerged. C) Flooded.

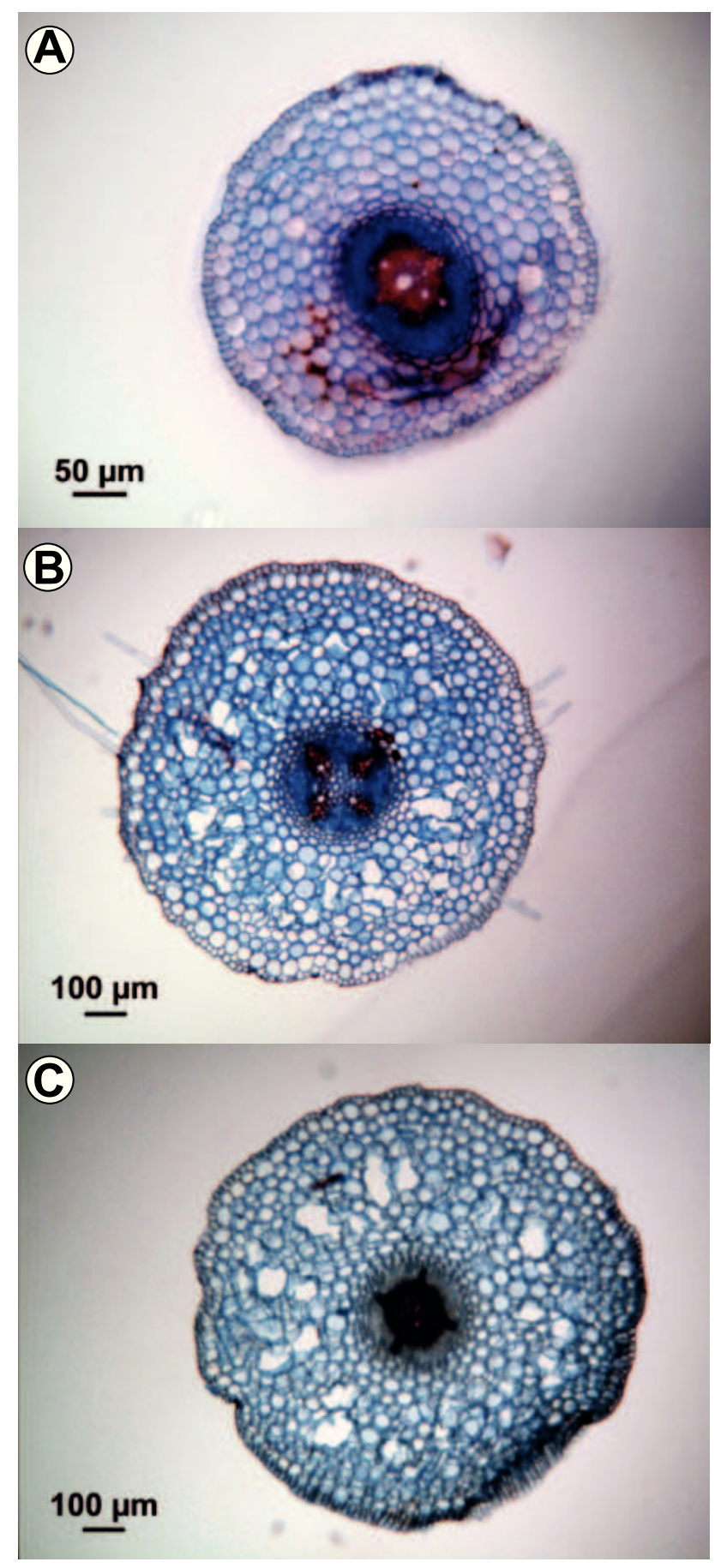

It was also noted that, in some cases, the epidermis of roots exposed to the flooded soil was ruptured. In Figure 2, the main differences among the three treatments can be observed (data not shown).

\section{Discussion}

In the gas exchange analyses there is an interplay between the parameters leaf photosynthetic rate $(\mathrm{Pn})$, stomatal conductance (gs) and intracellular concentration of $\mathrm{CO}_{2}(\mathrm{Ci})$. The reduction in these parameters in plants submitted to flooding, in relation to those submitted to the other two treatments, shows that the flooded soil had a negative effect on plant physiology. This is due to the fact that plant conditioning to flooded soils is followed by a rapid fall in the net photosynthetic rate, a response that can occur within hours or a few days (KOZLOWSKI, 1997). According to Grichko and Glick (2001), plants respond to flooding with reduced root permeability to water and minerals, which results in stomatal closure and leads to a reduction in the net photosynthetic rate.

It is well known that soil flooding can lead to water deficit conditions in plants, due to the reduction in root respiratory metabolism (HENRIQUE et al., 2010). According to Coelho et al. (2013), hypoxia in roots, as a result of flooding, triggers a series of metabolic changes involving the need to regulate the water balance and leads to stomatal closure. In these situations, there is a significant reduction in gs. Amaral et al. (2006) emphasize that a reduction in gs can cause a reduction in photosynthesis, since stomata are the main routes for gas exchange between leaves and the external environment.

The reduction of photosynthesis occurs due to a decrease in the intracellular concentration of $\mathrm{CO}_{2}(\mathrm{Ci})$ that passes through diffusion to the leaf mesophyll. Decreases in $\mathrm{Ci}$ might mean less $\mathrm{CO}_{2}$ available for ribulose-1,5-bisphosphate carboxylase/oxygenase (RUBISCO) activity, which is related to a decrease in Pn. A similar result was found by Martinazzo et al. (2013), who evaluated the effect of flooding on Prunus salicina Lindh. and concluded there was a reduction in the photosynthetic rate. In addition, the authors also associated Pn reduction to low stomatal conductance. Medri et al. (2012) evaluated the effect of flooding on 
the growth and metabolism of Aegiphila sellowiana Cham. and concluded that flooding caused a decrease in stomatal conductance and photosynthesis, resulting in limited plant development.

The ICE (instantaneous carboxylation efficiency) decreased as the amount of water in the soil increased. According to Machado et al. (2005), ICE represents the relationship between the photosynthetic rate and internal $\mathrm{CO}_{2}$ concentration. ICE values provide information about the carboxylation activity of RUBISCO and, consequently, its metabolic efficiency (CAMILLI et al., 2007). The results, obtained during the experiments in the present study, presented a higher ICE response for plants submitted to soil at field capacity and reduced ICE values for those submitted to flooding. This may have occurred since the stress caused by higher amounts of water in the soil led to a decrease in carboxylation activity of RUBISCO. According to Camilli et al. (2007), environmental or plant-related factors that affect photosynthesis and biological productivity may act on RUBISCO. Given the above, soil with a high level of water is an environmental factor that could be involved in the efficiency of RUBISCO, which can be roughly verified and estimated by the plunge of ICE values.

Data on leaf water potential (LWP) obtained by the Scholander pump did not show a statistical difference among treatments, which can be explained by the reduction in stomatal conductance and, consequently, a reduction in water loss (GRICHKO; GLICK, 2001; HENRIQUE et al., 2010). Likewise, since there were no statistical differences among treatments, it is possible that flooding did not cause a water deficit in the leaves that could lead to a change in proline production. In general, plants exposed to water stress may increase the intracellular concentration of proline, which represents an osmoregulatory mechanism of adaptation (MARIN et al., 2006). The increase of this amino acid concentration is related to a decrease in the relative water content in leaf tissues (MAIA et al., 2007). Therefore, the non-alteration of the observed proline content could be associated with the non-alteration of the leaf water potential and a certain tolerance of passion fruit seedlings to flooding.

The root anatomy parameters number of xylem (NX), diameter of xylem (DX) and diameter of phloem
(DP) had no statistical difference among treatments, which can be justified by the fact that apoplastic barriers (endoderm) increased in thickness, protecting the vascular cylinder from excess water and, consequently, morphological changes (ENSTONE et al., 2003).

The other parameters, root diameter (RD), epidermal thickness (EpT), thickness of cortex (TC) and thickness of endoderm (TEn), which presented increased values for the pre-submerged and flooded treatments compared to the soil at field capacity, may have suffered this increase due to the greater turgescence found in root cells exposed to flooding. Due to anatomical plasticity, some species may develop changes in the thickness of their tissues, which allows better acclimatization to different stress conditions (HENRIQUE et al., 2010). Greater turgescence leads to greater cellular expansion that, in turn, results in higher diameter and thickness values. Another possible consideration is that the formation of aerenchyma in the cortex of pre-submerged and flooded roots led to an increase in TC, which corroborates the data found by Davanso-Fabro et al. (1998). In addition, the increase in endoderm thickness (TEn) found in passion fruit plants may mean an increase in the apoplastic barrier to water uptake and $\mathrm{O}_{2}$ output from roots to soil, in order to reduce root permeability, and thus the anaerobic respiration due to hypoxia (GRICHKO; GLICK, 2001; LAVINSKY, 2013).

The parameter thickness of aerenchyma (TA) was only observed in the pre-submerged and flooded treatments, and some roots had a ruptured epidermis. This is an indication of the lysogenic aerenchyma formation process, which is important for surviving stress from flooding (TAIZ; ZEIGER, 2004). According to Grichko and Glick (2001), plants may respond to flooding with changes in hormonal balance. The lysogenic process occurs when ethylene production increases in the plant in response to hypoxia stress. As a result, this triggers and signals a cascade of reactions in the root cortical cells that lead to apoptosis by cell lysis and the opening of intercellular spaces that define the aerenchyma.

According to numerous authors, plants can survive flooding due to complex interactions among morphological, physiological and anatomical 
acclimations. The formation of aerenchyma represents one of the most important strategies of plant survival during flooding, since it allows the oxygen from the shoot to be stored in the roots, in order to maintain the metabolic process of aerobic respiration, which reduces damage by hypoxia (MARQUES; JOLY, 2000; FERREIRA et al., 2005).

Passion fruit (Passiflora edulis Sims) exhibited a set of physiological and anatomical changes during initial development, which allowed it to survive under pre-submerged and flooded conditions during the experiment. The main morpho-anatomical change observed for the seedlings under stress was the formation of aerenchyma, demonstrating the acclimation of these plants to the conditions to which they were exposed.

According to the results, it is possible to state that passion fruit seedlings at early stages can withstand large amounts of water in the soil. Therefore, exposure to a high rainfall index or excessive irrigation could provoke physiological adaptations in young passion fruit plants.

\section{Acknowledgements}

This study was supported by Coordenação de Aperfeiçoamento de Pessoal de Nível Superior (CAPES - Brazil) and Fundação de Amparo à Pesquisa de Minas Gerais (FAPEMIG - Brazil).

\section{References}

AMARAL, J. A. T. do; RENA, A. B.; AMARAL, J. F. T. do. Crescimento vegetativo sazonal do cafeeiro e sua relação com fotoperíodo, frutificação, resistência estomática e fotossíntese. Pesquisa Agropecuária Brasileira, Brasília, v. 41, n. 3, p. $377-$ 384, 2006.

BLOM, C. W. P. M.; VOESENEK, L. A. C. J. Flooding: the survival strategies of plants. Trends in Ecology \& Evolution, Cambridge, v. 11, n. 7, p. 290-295, 1996.

BUDKE, J. C.; JARENKOW, J. A.; OLIVEIRA-FILHO, A. T. de. Intermediary disturbance increases tree diversity in riverine forest of southern Brazil. Biodiversity and Conservation, New York, v. 19, p. 2371-2387, 2010.

CAlBO, M. E. R.; MORAES, J. A. P. V.; CALBO, A. G. Crescimento, condutância estomática, fotossíntese e porosidade do buriti sob inundação. Revista Brasileira de Fisiologia Vegetal, Campinas, v. 10, p. 51-58, 1998.
CAMILLI, L.; IKEJIRI, L.; KLEIN, J.; RODRIGUES, J. D.; BOARO, C. S. F. Produtividade e estimativa da eficiência de carboxilação in vivo da enzima rubisco em girassol ornamental cultivado em lodo de esgoto. Revista Brasileira de Biociências, Porto Alegre, v. 5, n. supl. 2, p. 858-860, 2007.

COELHO, C. C. R.; SILVA, J. N.; NEVES, M. G.; CONCEIÇÃO, A. G. C.; SILVA, R. T. L.; OLIVEIRA NETO, C. F. Aspectos ecofisiológicos e crescimento em plantas de milho submetidas ao alagamento. Revista Agroecossistemas, Belém, v. 5, n. 2, p. 41-46, 2013.

COLMER, T. D.; PEDERSEN, O. Underwater photosynthesis and respiration in leaves of submerged wetland plants: gas films improve $\mathrm{CO}_{2}$ and $\mathrm{O}_{2}$ exchange. New Phytologist, Lancaster, v. 117, p. 918-926, 2008.

DAVANSO-FABRO, V. M.; MEDRI, M. E.; BIANCHINI, E.; PIMENTA, J. A. Tolerância à inundação: aspectos da anatomia ecológica e do desenvolvimento de Sesbania virgata (Cav.) Pers. (Fabaceae). Brazilian Archives of Biology and Technology, Curitiba, v. 41, n. 4, p. 475-482, 1998.

ENSTONE, D. E.; PETERSON, C. A.; MA, F. Root endodermis and exodermis: structure, function, and responses to the environment. Journal of Plant Growth Regulation, New York, v. 21, n. 4, p. 335-351, 2003.

FERREIRA, C.; PIEDADE, M. T. F.; PAROLIN, P.; BARBOSA, K. M. Tolerância de Himatanthus sucuuba Wood. (Apocynaceae) ao alagamento na Amazônia Central. Acta Botanica Brasilica, Belo Horizonte, v. 19, n. 3, p. 425-429, 2005.

GONÇALVES, J. F. DE C.; MELO, E. G. DE F.; SILVA, C. E. M. DA; FERREIRA, M. J.; JUSTINO, G. C. Estratégias no uso da energia luminosa por plantas jovens de Genipa spruceana Steyerm submetidas ao alagamento. Acta Botanica Brasilica, Belo Horizonte, v. 26, n. 2, p. 391-398, 2012.

GRICHKO, V. P.; GLICK, B. R. Ethylene and flooding stress in plants. Plant Physiology and Biochemistry, Paris, v. 39, p. 1-9, 2001.

HENRIQUE, P. C.; ALVES, J. D.; GOULART, P. F. P.; DEUNER, S.; SILVEIRA, N. M.; ZANANDREA, I.; CASTRO, E. M. Physiological and anatomical characteristics of Sibipiruna plants under hipoxia. Ciência Rural, Santa Maria, v. 40, n. 1, p. 70-76, 2010 .

KOZLOWSKI, T. T. Responses of woody plants to flooding and salinity. Tree Physiology, Oxford, v. Monograph, n. 1, p. 1-29, 1997.

LAVINSKY, A. O. Efeito do silício na anatomia radicular e na produção de grãos de arroz. 2013. 94 f. Tese (Doutorado em Fisiologia Vegetal) - Universidade Federal de Viçosa, Viçosa. 2013.

LIMA, A. A.; SANTOS FILHO, H. P.; FANCELLI, M.; SANCHES, N. F.; BORGES, A. L. Coleção Plantar: Maracujá. Brasília: EMBRAPA, 1994. 76 p.

MACHADO, E. C.; SCHMIDT, P. T.; MEDINA, C. L.; RIBEIRO, R. V. Respostas da fotossíntese de três espécies de citros a fatores ambientais. Pesquisa Agropecuária Brasileira, Brasília, v. 40, n. 12, p. 1161-1170, 2005.

MAIA, P. S. P.; OLIVEIRA NETO, C. F.; CASTRO, D. S.; FREITAS, J. M. N.; LOBATO, A. K. S.; COSTA, R. C. L. Conteúdo relativo de água, teor de prolina e carboidratos solúveis totais em folhas de duas cultivares de milho submetidas a estresse hídrico. 
Revista Brasileira de Biociências, Porto Alegre, v. 5, n. 2, p. 918920, 2007.

MARIN, A.; SANTOS, D. M. M.; BANZATTO, D. A.; CODOGNOTTO, L. M. Influência da disponibilidade hídrica e da acidez do solo no teor de prolina livre de guandu. Pesquisa Agropecuária Brasileira, Brasília, v. 41, n. 2, p. 355-358, 2006.

MARQUES, M. C. M.; JOLY, C. A. Germinação e crescimento de Calophyllum brasiliense (Clusiaceae), uma espécie típica de florestas inundadas. Acta Botanica Brasilica, Belo Horizonte, v. 14, n. 1, p. 113-120, 2000.

MARTINAZZO, E. G.; PERBONI, A. T.; OLIVEIRA, P. B; BIANCHI, V. J.; BACARIN, M. A. Atividade fotossintética em plantas de ameixeira submetidas ao déficit hídrico e ao alagamento. Ciência Rural, Santa Maria, v. 43, n. 1, p. 35-41, 2013.

MEDRI, C.; PIMENTA, J. A.; RUAS, E. A.; SOUZA, L. A.; MEDRI, P. S.; SAYHUN, S.; BIANCHINI, E.; MEDRI, M. E. O alagamento do solo afeta a sobrevivência, o crescimento e o metabolismo de Aegiphila sellowiana Cham. (Lamiaceae)? Semina: Ciências Biológicas e da Saúde, Londrina, v. 33, n. 1, p. 123-134, 2012.

MELETTI, L. M. M. Avanços na cultura do Maracujá no Brasil. Revista Brasileira de Fruticultura, Jaboticabal, v. especial, p. 8391, 2011.

OLIVEIRA, V. C. DE; JOLY, C. A. Flooding tolerance of Calophyllum brasiliense Camb. (Clusiaceae): morphological, physiological and growth responses. Trees, Berlin, v. 24, p. 185193, 2010.
ROTONDANO, A. K. F.; MELO, B. Irrigação da cultura do maracujazeiro. 2015. Disponível em: <http://www.fruticultura. iciag.ufu.br/irriga8.html>. Acesso em: 7 mar. 2018.

SHINOZAKI, K.; UEMURA, M.; BAILEY-SERRES, J.; BRAY, E. A.; WERETILNYK, E. Responses to abiotic stress. In: BUCHANAN, B. B.; GRUISSEM, W.; JONES, R. L. (Ed.). Biochemistry and molecular biology of plants. 2 ed. West Sussex: Wiley Blackwell, 2015. p. 1051-1100.

SILVEIRA, N. M.; ALVES, J. D.; DEUNER, S.; DOUSSEAU, S.; HENRIQUE, P. C. Crescimento e partição de carboidratos em plantas de Sebastiania membranifolia submetidas ao alagamento. Cerne, Lavras, v. 21, n. 1, p. 67-74, 2015.

SOUZA, T. C.; CASTRO, E. M.; MAGALHÃES, P. C.; ALVES, E. T.; PEREIRA, F. J. Early characterization of maize plants in selection cycles under soil flooding. Plant Breeding, Westport, v. 131, n. 4, p. 493-501, 2012.

TAIZ, L.; ZEIGER, E. Fisiologia vegetal. 3. ed. Porto Alegre: Artmed, 2004. 719 p.

TORELLO, W. A.; RICE, L. A. Effects of $\mathrm{NaCl}$ stress on proline and cation accumulation in salt sensitive and tolerant turfgrasses. Plant and Soil, New York, v. 93, n. 2, p. 241-247, 1986.

VOESENEK, L. A.; COLMER, T. D.; PIERIK, R.; MILLENAAR, F. F.; PEETERS, A. J. How plants cope with complete submergence. New Phytologist, Lancaster, v. 170, p. 213-226, 2006. 